\title{
Evolution in land use and transportation research
}

Dea van Lierop, Geneviève Boisjoly, Emily Grise, \& Ahmed El-Geneidy

For Citation Please use: *van Lierop, D., *Boisjoly, G., *Grisé, E., \& El-Geneidy, A. (2017).

Evolution in land use and transport research. In T. Sanchez (Ed), Planning Knowledge and

Research. Routledge, New York, USA.

\section{Introduction}

Land use and transportation have a long and complex history of influencing one another, and this relationship has been studied through many dimensions over the past one hundred years. The role of land use and transportation researchers has been, and still is, to develop precisely measured, relevant, and reflective research that can help transport and planning professionals design effective policies and plans, as is mentioned in Chapter XX of this book. While researchers in this domain often conduct studies that lead to changes in planning practice, their research areas of focus are constantly evolving, and frequently influenced by the technologies, policies, and implementation of particular approaches to planning within a given context and time. The relationship between land use and transportation research and practice is therefore cyclical: practice is informed by research, and research interests stem from practical issues and trends.

The purpose of this chapter is to highlight and briefly discuss the main themes that land use and transportation researchers have focused on in order to present the evolution of land use and transportation research in a consolidated way. To begin the discussion on the evolution of research in land use and transport, it is useful to start with the first technological breakthrough that was significant for transportation and urbanization. The invention of James Watt's steam engine circa 1765 enabled the construction of the first steam locomotives, and consequently the opening of the first railway in 1825 (Vuchic, 
2007). Due to the ability to transport agricultural goods from rural regions to the urban core, and the increase in manufacturing job opportunities that the Industrial Era presented in urban areas, rural populations began to migrate to cities, causing large scale urbanization and urban expansion (Davis, 1955). As cities grew in geographic size and walking distances increased, people began to require a system that could transport them throughout urban areas. Accordingly, in the early nineteenth century intra-urban public transit systems first arose with the invention of the horse-drawn omnibus, mainly in European and North American cities (Vuchic, 2007). Soon after, the technology was improved by developing horse-drawn tramways that ran smoothly on rails instead of irregular cobblestone streets. As rails became a common and permanent urban infrastructural component (Neff \& Dickens, 2013), land use could now for the first time be planned and developed around existing transportation.

In the late nineteenth century, once electrification was popularized primarily throughout Europe and the United States, this innovative technology promoted the expansion of rail infrastructure in many cities (Garrison \& Levinson, 2006; Vuchic, 2007), and resulted in substantial changes to land use. For example, based on his analysis of changes in rail network density and population density during the $19^{\text {th }}$ and $20^{\text {th }}$ centuries in London, Levinson (2007) found the presence of a positive feedback loop, which meant that increases in population density motivated the construction of rail stations and vice-versa. This suggests that the introduction of electrically run trains had a strong influence on urban land use development as it enabled cities to expand and develop suburbs near commuter rail stations outside of the city centers (Garrison \& Levinson, 2006). Consequently, as cities continued to expand, and people needed to travel longer distances, the demand for public transit grew stronger as no other modal competition was yet present. Tramway technologies and vehicle design improved, which allowed public transit to service more areas in cities and suburbs, contributing to its popularity (Neff \& Dickens, 2013; Vuchic, 2007). Accordingly, by the time WWI started, electric railways had become "the backbone of urban mass transportation” (p.12) in many North American (Weiner, 1999b) and European cities.

As public transit systems, and especially rail, continued to have a more permanent presence in cities (Aman, 1911; Weiner, 1999b), researchers began to study the integration 
between land use and transportation and the effect it had on where individuals and firms chose to locate (Weber \& Pick, 1909). However, this communal way of moving through urban areas changed in the $1920 \mathrm{~s}$, when the private automobile became increasingly popular and presented a new way of moving around the city. The competition between modes significantly decreased public transit ridership, and the popularity of the automobile led to increased traffic congestion, road accidents and air pollution in cities (Barrett, 1983; Foster, 1981; Raff, 1991). Due to the new demand for road space resulting from the increase in automobile use, in the 1920s and 1930s transportation researchers focused primarily on traffic studies in order to develop a systematic understanding of traffic flows (Garrison \& Levinson, 2006; McClintock, 1926).

No form of urban mobility has affected land use as dramatically as the invention and widespread usage of the automobile, as well as the subsequent creation of present day auto-dependent culture that exists in many cities around the world today (Wachs, 1993). The convenience of the personal automobile, availability of inexpensive fuel, and policies such as the 1956 Interstate Highway Act in the United States and the Special Roads Act 1949 in the United Kingdom facilitated the suburban development that reflected urban dwellers' location preferences, and consequently allowed for outward migration from city centers (Levinson \& Krizek, 2008; "Special Roads Act 1949," 1949). Suburbs could be developed across waterways and other geographic barriers as innovations in the production of steel, concrete, and bridge design allowed car users to commute from further out of the city at high speeds that enabled travel times to remain consistent (Levinson \& Krizek, 2008; Shahrooz, 2011).

Due to advancements in infrastructure and transportation technologies, commuters could now travel further distances, and city centers could draw on a larger labor pool (Garrison \& Levinson, 2006). Consequently, the interaction between transportation and land use began to be formally studied, as for example by Alonso (1964), who developed land rent models that assessed the relationship between housing prices and transportation costs. Assuming an urban area with a single market location, Alonso, as well as other researchers at the time, built statistical models to determine the trade-off costs that influence individuals' home location and transportation choices. As more people began to choose to locate on less expensive suburban land and pay for higher travel costs, congestion 
levels increased in urban areas. In line with the research focus on traffic flows, roads were expanded to account for the new volume of automobiles. These increases in road capacity were shown, however, to be an ineffective solution to alleviate traffic. In many cases it led to more congestion, which would in turn lead to greater increases in road capacity, resulting in a positive feedback loop (Downs, 2004).

Given the growing interest in land use and transportation research, several regions in the United States began to develop land use and transportation plans based on large travel behavior surveys in order to relieve congestion. For example, the metropolitan transportation study known as CATS (Chicago Area Transportation Study) was the first systematic region wide study which accounted for both transportation and land use. This study led to the release of one of the first comprehensive land use and transportation plans in the early 1960s. At this time, the plan was considered extremely progressive as " $[i] t$ pioneered in the use of computers, trip distribution, traffic assignment, and benefit-cost analysis” (Black, 1990).

Although auto-dependent societies experienced increases in mobility, many negative externalities pertaining to the environment, social wellbeing of communities, and the economy were felt in cities. As a reaction, research in transportation and land use began to place a new emphasis on understanding how to lessen the detrimental impacts on the environment that had largely been caused by the consumption of fossil fuels (Belzer \& Autler, 2002; Cervero, 2004; Cervero, Ferrell, \& Murphy, 2002). Furthermore, increases in congestion and infrastructure costs associated with suburban auto-dependent communities were understood to have negative economic consequences (Newman \& Kenworthy, 1996; Podobnik, 2002). In recent years, these environmental, social and economic impacts associated with auto-dependent lifestyles have continued to receive much attention. Overall, it has become increasingly clear to planners that land use and transportation planning are inherently interconnected, as land use development influences transportation planning, and vice versa (Gutierrez, 2009). Researchers are therefore key actors in the generation of knowledge relating to complex and constantly evolving land use and transportation advancements.

This chapter illustrates how research on transportation and land use has evolved over time by briefly discussing several main research themes. The first section of this 
chapter discusses research related to accessibility, which is a core theme integrating land use and transport research, and is followed by a discussion of integrated land use and transportation models. Research on travel behavior is then presented, followed by a discussion of environmentally sustainable urban forms. The chapter concludes with a discussion on emerging research trends, namely equity, gentrification, and planning for sustainable cities. Figure 1 depicts the evolution of land use and transport research that is discussed. At the bottom of the figure, important dates in the history of transportation are included for reference. These dates are primarily based on Vuchic's (2007) book on urban transit technology. Furthermore, the boxes on the left side of the figure correspond to the subsections presented in this chapter. 
EVOLUTION OF LAND USE

AND TRANSPORTATION RESEARCH

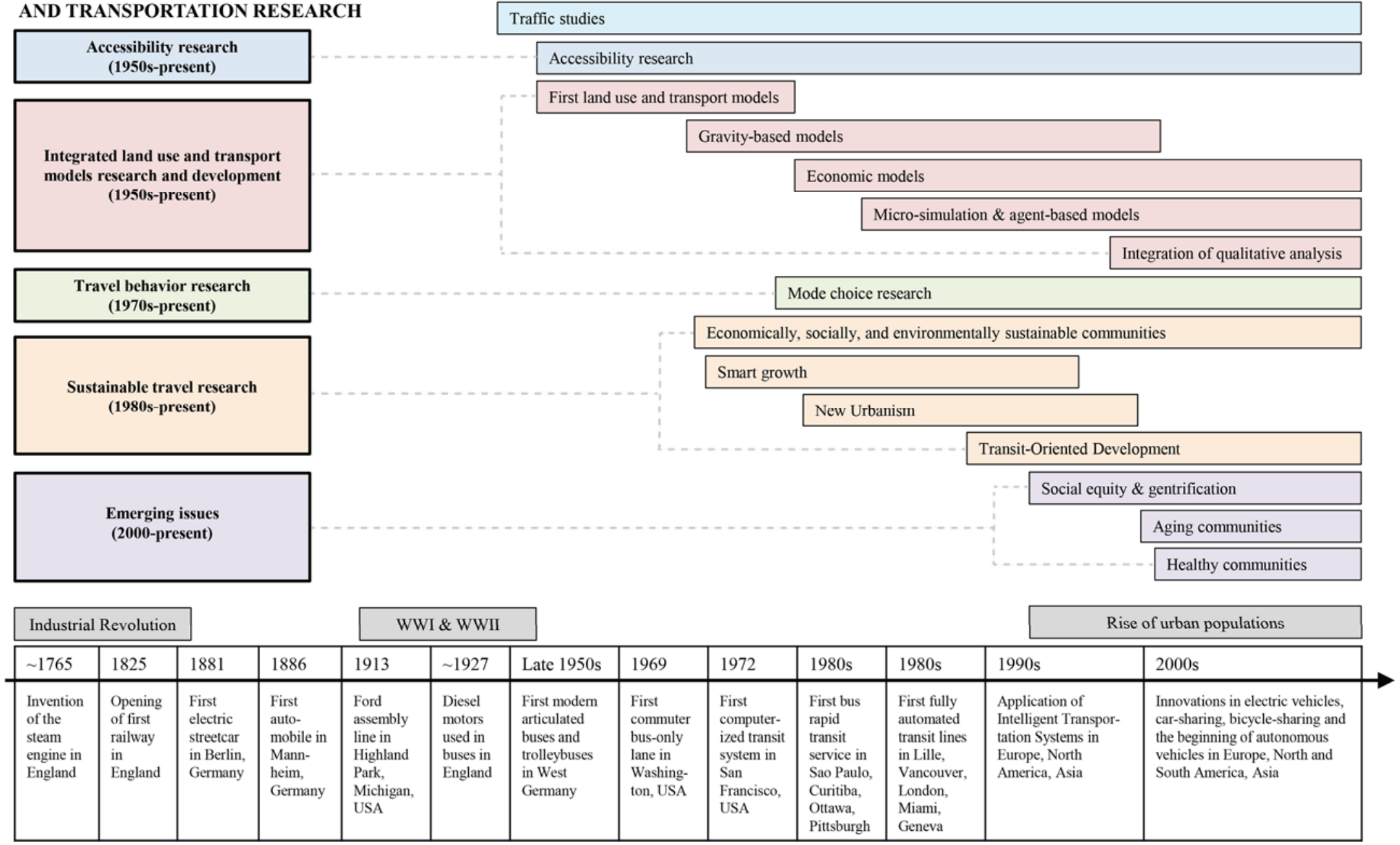

Figure 1: The evolution of land use and transportation research 


\section{Integrating transportation and land use through accessibility}

One of the most important trends in the literature of land use and transportation is related to accessibility research. While transportation research started as an isolated field focusing on mobility, which refers to the ability to move from one place to another, most people travel because they need or want to access particular destinations. Thus, researchers recognized that transportation policies should aim at increasing access to destinations rather than solely focusing on mobility. Whereas traffic studies, which were primarily focused on mobility, depended solely on the transportation system itself, the concept of accessibility, understood as the ease of reaching various destinations (Preston \& Rajé, 2007), was developed to also be contingent on the location of urban opportunities. Accessibility research hence addresses the complex interaction between the location of economic and residential activities and the transportation network in a city (Guiliano, 2004). It also helps to understand the impacts of such interactions on location patterns, travel behavior and, most importantly, quality of life.

The concept of accessibility was introduced by Hansen in 1959. In his widely-cited

paper "How accessibility shapes land use", Hansen proposed a method for determining accessibility patterns in a region (Hansen, 1959). He defined accessibility as "the potential of opportunities for interaction” (p.73), which he measured based on the travel time to various opportunities from a specific location (employment, shopping opportunities and residential activity (population density)). In this gravity-based model, each opportunity was weighted based on the travel time associated with reaching an opportunity. The further an opportunity was located from an origin, the less it contributed to accessibility, meaning that closer opportunities were deemed to be more desirable. Using this model, Hansen was interested in predicting the development of residential land use in a region.

Inspired by Hansen's early work on accessibility, researchers continued to focus on the relationship between land use development and accessibility (Ball \& Kirwan, 1977; Nelson, 1973), looking at the trade-offs between accessibility and housing prices, and the location choices of households as a function of accessibility. These studies provided 
researchers with a better understanding of land use development patterns as a function of proximity to opportunities, in terms of time or distance.

Another branch of accessibility research emerged in the 1970s evaluating the impacts of access to urban opportunities on individuals. At this time, accessibility was framed as the benefit resulting from a transportation and land use system (Ben-Akiva \& Lerman, 1979). The influence of accessibility on the quality of life of individuals was highlighted, specifically with respect to transportation costs and employment opportunities (Wachs \& Kumagai, 1973). In line with this new perspective, Wachs \& Kumagai (1973) made the case for including accessibility in the evaluation of transportation and regional plans. More specifically, they studied the "distributional effects of policies" using accessibility indicators, which they defined as "the physical accessibility of population groups to a variety of activities and opportunities" (p.437-438).

These accessibility indicators were presented to complement mobility indicators, which dominated transportation planning throughout most of the $20^{\text {th }}$ Century. As noted in the introduction, the first transportation and land use plans were based on travel behavior survey with the aim of alleviating congestion. In this context, several researchers argued that accessibility measures, typically based on the number of opportunities that could be reached from a specific location using a specific mode, more accurately emphasized the needs of individuals (Koenig, 1980; Wachs \& Kumagai, 1973), whereas mobility measures merely addressed travel time minimization and fluidity of car traffic (Banister, 2008). Transportation planning today continues to be dominated by mobility indicators, although many researchers are actively attempting to demonstrate the relevance of accessibilitybased approaches (Banister, 2008; Levine, Grengs, Shen, \& Shen, 2012).

Up until the year 2000, the concept of accessibility had been researched and discussed, but not often translated into practical performance measures (Handy \& Niemeier, 1997). These discussions were mainly conceptual and theoretical given the lack of advanced computational methods. However, due to increases in computational power and development of advanced software, a plethora of measures and empirical studies were developed at the end of the $20^{\text {th }}$ century and applied to research concerning mode choice, (un)employment, land values and social equity (Armstrong \& Rodriguez, 2006; Blumenberg \& Ong, 2001; Currie, 2010; Du \& Mulley, 2006; El-Geneidy \& Levinson, 
2006; Geurs \& van Wee, 2004; Grengs, 2010; Martens, Golub, \& Robinson, 2012; Paez, Scott, \& Morency, 2012; Sanchez, Shen, \& Peng, 2004). In addition some recent research focused on evaluating the benefits from different scenarios in transportation plans (ElGeneidy, Cerdá, Fischler, \& Luka, 2011; Golub \& Martens, 2014; Manaugh \& El-Geneidy, 2011). More recent developments have focused on methodological aspects, namely integrating fluctuations of accessibility throughout the day (Anderson, Owen, \& Levinson, 2012; Boisjoly \& El-Geneidy, 2016).

Although both conceptually and empirically accessibility has been the focus of much research, its application to planning is still limited. While regional and transportation plans are increasingly including accessibility goals and indicators, the focus still lies largely on mobility aspects. Research has thus emerged on the implementation of accessibility in planning (Halden, 2011; Proffitt, Bartholomew, Ewing, \& Miller, 2015), and further research in the formal and practical application of accessibility is needed.

\section{Integrated land use and transportation models}

One way that researchers have formalized the study of the relationship between land use and transportation is by developing mathematical and statistical methods analyzing the complex relation between changes in land use, economic activity, and transportation options. The first land use and transportation models appeared in the 1950s (Batty, 2008), and by the 1960s many operational models were developed to better understand the relationship between land use and transportation. The most advanced of these early models was Lowry's (1964) Model of Metropolis which was developed for the Pittsburgh region and used various simulation techniques including complex econometric analysis as well as gravity modelling. Lowry's model represented a breakthrough in the development of methods used to analyze and simulate the spatial interaction between residential and service locations, which marks an important beginning to modelling the interactions between land use and transportation. Lowry's model was further developed by Garin (1966) to improve how the interaction between land use and transportation was modeled (Iacono, Levinson, \& El-Geneidy, 2008). During the 1970s, researchers continued to develop spatial 
interaction models to predict how policy changes in land use and transportation would influence one another.

The first fully complete software package integrating land use and transportation was developed in the early 1980s by Putman. Putman's Integrated Transportation and Land Use Package (ITLUP) included two land use sub-models, one representing household characteristics and the other accounting for employment details. With respect to transportation, this model accounted for travel time and was the first to account for congestion at different times of the day (Putman, 2013). Other spatial interaction models were also developed (Iacono et al., 2008; Mackett, 1983), but most of these models soon lost their popularity for four main reasons: "most were static equilibrium models incapable of capturing the dynamics of urban systems; none of the models actually represented land markets with explicit prices; zones were highly aggregate and lacked spatial detail, and the models were inadequately supported by theory” (Iacono et al., 2008, p.5).

By the mid-1980s, random utility theory and economic methods became increasingly popular as researchers searched for ways to better capture individuals' choices (for example, travel behavior and location preferences) in their modeling methods. The new land use and transportation models were based on theories that had previously been used for regional economic models and land market models (Iacono et al., 2008). For example, TRANUS was developed to simulate the interactions between land use, transportation, activities, and the real estate market using discrete choice logit models (De la Barra, 1989). This research was further developed in the 1990s when dynamic models were able to integrate multiple sub-models which included information about topics such as housing markets, employment, vacant lands, households, and travel behavior (Anas \& Arnott, 1994; Iacono et al., 2008; Martinez, 1996).

In the late 1990s and early 2000s, Waddell developed UrbanSim to assist urban planners in making decisions about land use, transportation, and environmental planning (Brail \& Klosterman, 2001; Waddell, 2000; Waddell, Outwater, Bhat, \& Blain, 2002). UrbanSim symbolized an advancement in land use modelling as it was based on spatially disaggregated analysis and could be associated with complex transportation models (Waddell et al., 2002). Extensions were developed to incorporate a traditional four step transportation model, to predict trips based on activities (Waddell et al., 2002) and to 
include environmental analyses (Waddell \& Borning, 2004). Furthermore, UrbanSim was designed to be integrated with Geographic Information Systems (Iacono et al., 2008). UrbanSim progressed for more than two decades and eventually incorporate agent-based modeling techniques. Agent-based modelling systems, which are also based on disaggregate analyses, are considered to be more useful than aggregate modelling systems because they more accurately account for complexities related to modelling human socioeconomic activities. UrbanSim continues to be used today in many regions around the world, due to the open source nature of the project, the absence of initial costs and the various successes made by developers in implementing it.

Another agent-based model that was developed in the early 2000s is Salvini and Miller's ILUTE (2005), which uses a variety of modelling approaches to accurately simulate land use, location choice, car ownership, and travel patterns, otherwise referred to as activities. This model, which is currently applied to the Greater Toronto Area, also accounts for temporal elements. Miller also worked with Roorda (2003) to develop the Travel/Activity Scheduler for Household Agents (TASHA) model. Similarly to other activity-based travel demand models, this model uses a micro-simulation system (Acheampong \& Silva, 2015). This is helpful for modelling the complexities of how transportation and land use are interconnected at the individual level and has also been applied in Toronto, Canada. Additionally, environmental aspects were later incorporated into the TASHA model (Hatzopoulou, 2009). Currently, researchers are continuing to develop similar models in different metropolitan regions (Katoshevski, Glickman, Ishaq, \& Shiftan, 2015; Waddell, Wang, Charlton, \& Olsen, 2010).

Even though these agent-based models represent a major advancement in the simulation of land use and transportation interactions and are commonly used today in practice, they remain computationally complex, require large amount of data, and must be developed as context specific models. Given these constraints, integrated models are not easily transferrable although it is often believed that they are. Today, many researchers are continuing to develop and improve land use and transportation models as they are important for testing planning theories and potential policies - especially with regard to accessibility. Wegener's (2004) comparative review of integrated land use and transportation models provides a detailed assessment of available models according to their 
predicted ability to impact policy. One new area of focus is the use of qualitative tools to examine, and better model, the relationships between transportation and land use. For example, Pfaffenbichler's Metropolitan Activity Relocation Simulator (MARS) developed in Vienna, Austria integrated qualitative measures into an otherwise quantitative model (Pfaffenbichler, 2003, 2011). Other authors have suggested that a paradigm shift in land use and transportation modelling is needed to account for land use and transportation variations within existing urban areas, changes in the behavior of different populations (van Wee, 2015) and the effects of climate change (Wegener, 2011).

The development of integrated land use and transportation models has progressed along a similar timeline as accessibility research as these two topics are closely related. Accessibility is dependent on transportation and land use systems, and in turn affects both land use development and individuals' travel patterns. Accordingly, many of these models incorporated and benefited from advancements in accessibility and travel behavior research. The ongoing development of integrated model has significant impacts on the ground, as many agencies are adopting them to help in the decision making process. Further research will contribute to developing finer models that account for a greater diversity of qualitative and quantitative measures as well as spatial and individual variations.

\section{Understanding and influencing travel behavior}

Research on travel behavior emerged at the same time as research on accessibility and integrated land use and transportation models. In the context of widespread automobile use, suburbanization, and traffic congestion, planners and researchers became interested in understanding and predicting travel flows in order to better plan the transportation and land use system to meet demand. This was done through the expansion of the road network and the development of new residential areas. The aim was to understand when and where people travelled, with a focus on private motorization. This traditional planning approach was based on predicting the demand, and then providing infrastructure to meet that demand. This led to the development of the four step model, which was implemented in the 1950s in Detroit and Chicago (Weiner, 1999a), and was designed to predict travel 
demand and accounted for trip generation, trip distribution, mode choice and route choice (McNally, 2007).

Mode choice later became predominant in travel behavior studies. While transportation models were generally used to predict travel patterns at the regional level and to understand how policies would influence land use and transportation, research on mode choice focused on investigating travel patterns from an individual's perspective (Hurst, 1969). More specifically, it concentrated on predicting whether investing in public transit would be an effective policy as an alternative to expanding highways, and whether it would contribute to reducing automobile ownership and use (Button, Pearman, \& Fowkes, 1982; McFadden, Johnson, \& Reid, 1973). As a result, a considerable amount of research started to focus on assessing individuals' transit usage and automobile ownership (Banister, 1978; Kain \& Beesley, 1965; McFadden et al., 1973). The goal of this research was to understand automobile ownership in relation to transit infrastructure (Button et al., 1982; Kain \& Beesley, 1965), in an effort to identify policies that could help reduce automobile ownership, and thus traffic congestion. With respect to transit use, McFadden (1973) developed a discrete choice model and predicted the probability of using public transit based on trip and individual characteristics such as travel time by different modes, income and ethnicity. Using this model, McFadden and his colleagues predicted the travel demand and financial feasibility for the Bay Area Rapid Transit (BART) system in the San Francisco region (McFadden et al., 1973). McFadden's predictions about the BART turned out to be accurate. Official forecasts predicted $15 \%$ of commuting trips to be made on the BART, whereas McFadden predicted 6.3\%, and the actual mode share turned out to be 6.2\% (McFadden, 2001). Although McFadden's model accurately predicted ridership, the transport planners working at BART never used his modelling techniques to develop policies (Button, Doh, Hardy, Yuan, \& Zhou, 2010). Interestingly, McFadden later won a Nobel Prize for his work on discrete choice analysis.

Following McFadden's research, multiple modal split models have been developed to capture the diversity of factors influencing mode choice. Namely, land use characteristics such as employment and residential density have been included in later models (Kain \& Fauth, 1978; Train, 1980). Furthermore, a concurrent growing interest for accessibility research influenced other researchers to investigate the impact of accessibility 
on travel behavior, namely trip rate and mode choice (Ben-Akiva \& Lerman, 1974; Koenig, 1980). Today, similar mode choice models continue to be developed and used, specifically with respect to accessibility (Legrain, Buliung, \& El-Geneidy, 2015; Levinson, 1998; Owen \& Levinson, 2015).

In addition to quantitative modal split models, travel behavior research has been characterized by a will to understand psychological factors influencing mode choice. Researchers became interested in understanding how individuals' habits, perceptions and motivations affected where, when, and by which mode people traveled (Hensher, 1975). While the quantitative studies looked at personal characteristics such as gender and age, this new branch of mainly qualitative research went beyond these characteristics to understand how psychological factors, such as personal perceptions and values affect mode choice.

The travel behavior research described here contributed to a greater awareness of the influence of the urban form and the transportation network on travel behavior of individuals. Together with the growing environmental concerns related to automobile use, this led to a greater focus on the built environment and its relation to transportation infrastructure and travel behavior.

\section{Promoting sustainable travel through urban form}

As researchers began to identify elements of the built environment that impacted travel behavior, developing urban forms that promote the use of sustainable modes became one of the most popular and practiced strategies aiming to counter the negative effects of autodependent lifestyles (Cervero, 2004; Chatman, 2013; Samuelson, 2009). Following the oil and energy crisis experienced by industrial countries during the 1970s, many cities around the world have actively focused on developing communities where walking, cycling, and public transit are viable alternatives to private motorized vehicles. Research in this area has accordingly focused on understanding how to best integrate land use and transportation infrastructure with the goal of decreasing auto-dependent lifestyles while developing urban environments that yield social, economic and environmental benefits. 
Planners and researchers first focused on inner-area revitalization as a way to redirect a portion of urban growth closer to the city center, combined with controlled and limited outward urban development. Researchers emphasized that inner-area revitalization should be composed of attractive communities with integrated living and working environments, supporting non-motorized modes of transportation and inter-modalism (Burchell, Listokin, \& Galley, 2000; Duany, Speck, \& Lydon, 2010; Podobnik, 2002). This strategy, now referred to as Smart Growth, was first discussed in the 1970s, and continues to be discussed today although not often applied in practice (Downs, 2005).

Following the emergence of the Smart Growth principles, increasing attention was given to the integration of land use and transportation at the neighborhood level. This led to the New Urbanism movement, which was informally developed in the United States in the early 1980 s to promote the development of sustainable neighborhoods, and formally documented through the publication of the "Charter of the New Urbanism" in 1999 (Congress for the New Urbanism, 1999; Duany, 2013; Talen, 2013). New Urbanism is similar in principle to Smart Growth, but more codified in its prescriptions for design standards. Overall, it aims to generate compact, pedestrian-friendly, and more livable communities by including vibrant public spaces, amenities located at the center of the development, and a transit station or stop (Burchell et al., 2000; Leccese \& McCormick, 2000).

As with Smart Growth and New Urbanism, transit-oriented development (TOD) has received much attention among both planners and land use and transportation researchers since the early 1990s - especially throughout North America (Dunphy et al., 2004). The application of TOD theory seeks to increase land use densities and develop mixed use communities near rail stations in order to encourage public transit use and dissuade auto-dependent lifestyles with the goal of generating more sustainable communities. Similarly to other strategies aimed at developing sustainable communities, TODs focus largely on the built environment. Researchers, therefore, further explored the interconnections between public transit infrastructures and the built environment in this context. Cervero and Kockelman (1997) identified three elements that are essential components in the integration of land use and transit for reducing auto use: density, diversity and design, also called the 3Ds. In general, researchers and practitioners agree 
that these three elements are essential components needed to develop vibrant built environments necessary for the success of TODs (Cervero \& Kockelman, 1997; van Lierop, Maat, \& El-Geneidy, 2016). Recently, these three components have been expanded upon to include destination accessibility, distance to transit, and demand management, which includes parking supply and cost (Ewing \& Cervero, 2010; Translink, 2010). Ewing and Cervero (2010) continued research in this area and found a seventh 'D,' demographics, highlighting its influence as a confounding factor with respect to travel behavior while recognizing that it is not a component of the built environment. However, Cervero and Kockelman's original 3Ds comprising the built environment are still predominant in the literature, and research in this area often focuses on understanding whether the densification and discouragement of automobile use associated with both existing and new TODs successfully yield significant environmental, social, and economic benefits for cities (Dunphy et al., 2004; Hofstad, 2012; Renne \& Wells, 2004). Knowing that the spatial structure of homes, jobs, and facilities creates the context within which people travel, several studies have found that planned sustainable communities influence the use of active and sustainable modes (Langlois, van Lierop, Wasfi, \& El-Geneidy, 2015). Accordingly, Ewing and Cervero (2010) emphasized that "[t]he potential to moderate travel demand by changing the built environment is the most heavily researched subject in urban planning" (Ewing \& Cervero, 2010, p. 267).

However, not all researchers agree on the extent to which the built environment influences mode choice and travel behavior. Several researchers have found that individuals who have an inclination to commute by public transportation or active modes tend to locate themselves in walkable neighborhoods with sufficient access to transit, which is referred to as self-selection (Chatman, 2006, 2009; Handy, Cao, \& Mokhtarian, 2006; Manaugh \& El-Geneidy, 2014). Yet, regardless of the current academic debates, in practice, urban planning theories that accept the influence of the built environment on travel behavior, and seek to decrease automobile use and mitigate the impacts associated to automobile dependency, continue to receive much attention (Burchell et al., 2000; Cervero \& Kockelman, 1997; Hofstad, 2012; Renne \& Wells, 2004).

Overall, the abundant research on the influence of the built environment has helped planners develop local policies supporting the development of sustainable communities. In 
turn, the implementation of such policies by practitioners has provided researchers with a variety of empirical case studies to deepen their understanding of the impact of the built environment on travel behavior.

\section{Emerging issues in transport and land use} research

In parallel with inner-city revitalization projects such as Smart Growth, there has been a dramatic return to the city movement. These urban locations became more desirable, particularly for more affluent, educated working professionals, and as a result triggered the onset of gentrification. The term gentrification was originally coined by sociologist Ruth Glass (1964), and later researched by Neil Smith who found that land in proximity to transportation systems was more desirable, which in turn led to higher land value (Smith, 1982). The widespread effect of gentrification has attracted considerable research to uncover its processes, as well as the effects of gentrification on less affluent populations. While few studies have found a positive change associated with the process of gentrification, namely as a result of neighborhood revitalization (Freeman, 2005), the majority of literature describes the adverse effects of gentrification (Grube-Cavers \& Patterson, 2015; Walks \& Maaranen, 2008). The growth of income polarization within newly gentrified neighborhoods is seen as the main negative impact of gentrification (Walks \& Maaranen, 2008). Furthermore, the process of gentrification poses a range of problems for planners, as it displaces low-income households who must often settle for accommodation in regions with poorer transit accessibility, farther distances from work and fewer public services available (Walks \& Maaranen, 2008). Consequently, gentrification research is largely tied with concerns for social equity. Inequities in the context of transportation planning often result from inequalities in the distibution of transportation supply. This can be a result of inequitable planning, population displacements or limited location choices, and the corresponding benefits that the transportation system offers to different populations (Jones \& Lucas, 2012). 
In parallel with research on public transit accessibility and land values, similar trends have been found for active transport modes. Namely, a positive relationship between housing prices and neighborhoods with higher walkability (Pivo \& Fisher, 2011) and availability of bicycle share stations (El-Geneidy, van Lierop, \& Wasfi, In press) has been observed. The desirability of neighborhoods that facilitate the use of active modes of transportation may reflect higher levels of social and community engagement found in more walkable, mixed use neighborhoods when compared to automobile-oriented suburban neighborhoods (Leyden, 2003). In addition, the potential benefits to an inidividuals' health through increased physical activity (Shephard, 2008), and the affordablility and convienience offered by active travel have been found to be desirable. However, while progressive transportation planners have promoted investments in active transport infrastructure, recent evidence of an inequitable distribution of cycling infrastructure investment has been observed (Flanagan, Lachapelle, \& El-Geneidy, 2016), and concerns of infrastrucutre improvements as a reflection of gentrification efforts have been expressed (Lubitow \& Miller, 2013). The inclusion of equity principles in transportation planning as well as the acknowledgement of inequalities in the transportation system is now seen as crucial to ensure that all individuals can access desired opportunities. Research in this field contributes to define equity in the context of transportation (Martens et al., 2012; Pereira, Schwanen, \& Banister, 2016) and researchers today are continuing to develop tools to measure inequalities in the distribution of transportation supply (Delbosc \& Currie, 2011; Manaugh \& El-Geneidy, 2011).

As the world's urban population continues to rise, transit agencies and governments are also faced with the challenge of meeting the increased demand of intra-urban transportation, primarily by increasing the share of individuals who choose sustainable modes of transportation. Traditionally, cost, time and distance were believed to be the most significant factors driving the selection of an individual's transportation mode (Button, 2010). However, while trip characteristics remain important determinants of travel behavior, research has shown that travel behavior is a function of both internal and external factors unique to an individual, including personal motivation, values, and sociodemographics (Boarnet \& Sarmiento, 1998; Van Acker, Van Wee, \& Witlox, 2010). Furthermore, attitudes towards travel are important considerations within travel behavior 
modeling. For example, Ory and Mokhtarian (2005) observed that individuals with a positive attitude toward travel in general may be less likely to reduce their travel through behavioral changes such as living in a mixed-use neighborhood.

Additionally, an individual's mode choice has several implications on health, and new areas of research related to how the built environment affects health and overall wellbeing have emerged. For example, Ettema, Gärling, Olsson, and Friman (2010) found that daily travel can be a stressful event affecting subjective well-being, and similarly, other researchers have suggested that commuting stress is related to causing adverse effects on individual's health, such as exhaustion, depression, and feelings of poor health (Gee \& Takeuchi, 2004; Hansson, Mattisson, Björk, Östergren, \& Jakobsson, 2011). Moreover, the negative effects of stress while commuting are likely felt most by drivers, whereas active transport modes are less stressful (Legrain, Eluru, \& El-Geneidy, 2015), and increase levels of physical activity. Given that research has demonstrated the multiple health benefits associated with active modes, walking was placed in high priority on the public health agenda after the 1996 United States Surgeon General's report on physical activity (United States Department of Health \& Human Services, 1996). This led to widespread research on environmental influences of physical activity and best practices and policies for urban design (see review by Heath et al. (2006)). More recently, the Surgeon General reiterated the need to address public health through walkable communities in his 2015 Call to Action (United States Surgeon General, 2015). The growing evidence of the impact of our land use and transportation patterns on our health and our social well-being, spurs considerable interest in this field for the future.

Finally, land use and transportation planners and researchers today are presented with the challenge of how to adapt systems based on the needs and desires of an aging population. By 2030 at least $25 \%$ of major urban areas of the developed world will be 60 years and older (United Nations, 2013). This demographic shift presents far-reaching implications for society. Cities produce advantages for older people, such as higher accessibility to essential services as well as leisure and social activities, and developing age-friendly cities remains an important planning goal (Phillipson, 2011) and research agenda. Trends of increasing auto-dependency of contemporary and future generations of seniors' (Newbold, Scott, Spinney, Kanaroglou, \& Páez, 2005; Rosenbloom, 2001) present 
researchers with the challenge of how to develop age-friendly cities with viable transportation options. Access to different modes of transportation has been identified as a key factor affecting the mobility of seniors and consequently their quality of life (Banister \& Bowling, 2004).

Another population of interest to researchers is the Millennials, who have embraced the sharing economy, generating interest in research on car-sharing, as well as emerging transport technologies, such as electric vehicles and autonomous vehicles. Accordingly, research in these areas has started to emerge in recent years. Yet, due to the new nature of this topic, the impacts on land use have been limited to research, and are up until now solely theoretical. However, major land use changes resulting from the influence of emerging transportation technologies are expected to occur in the near future.

\section{Chapter wrap up}

This chapter has demonstrated that land use and transportation planning are strongly interconnected. Moreover, land use and transportation research is now a mature subfield of both transportation and urban planning research, and research in this area was consolidated through the establishment of the World Society for Transport and Land Use Research (WSTLUR), in 2008. To support the dissemination of the growing body of literature on land use and transportation. The Journal of Transport and Land Use (JTLU) is now the official journal of WSTLUR. Also WSTLUR organizes a World Symposium on Transport and Land Use Research every three years and selected articles form this symposium are published in JTLU.

Overall, this chapter has brought attention to the major themes that have emerged in land use and transportation research over the past century. While well-established research areas such as those related to accessibility, land use and transportation modelling, mode choice, and the development of sustainable communities continue to be studied, today's research tends to emphasize the less tangible aspects of land use and transportation, such as social equity, individuals' perception and experience of transportation, and attractiveness of the built environment for different populations. Considerable progress has 
been made towards a greater understanding of these factors. Nevertheless, as new technologies continue to emerge in cities, a new era of transportation and land use research is beginning to emerge. For example, there are many opportunities for land use and transport interaction with regard to Intelligent Transportation Systems and other Smart City technologies both in the near and distant future. These technologies will inevitably bring significant changes to land use and transportation systems, and thereby add new dimensions to all subfields of land use and transportation research. Major challenges therefore remain in bridging the gap between research and planning practice, and must be fully considered by researchers in order to develop sustainable cities that meet the needs of all individuals.

\section{Acknowledgment}

The authors would like to thank Porf. David Levinson for providing feedback on an earlier version of the manuscript. Also thanks to Prof. Thomas Sanchez for his feedback and help in putting this article together. 


\section{References}

Acheampong, R., \& Silva, E. (2015). Land use-transport interaction modeling: A review of the literature and future research directions. Journal of Transport and Land Use, 8(3).

Alonso, W. (1964). Location and land use. Toward a general theory of land rent. Location and land use. Toward a general theory of land rent.

Aman, F. (1911). Vienna: The Tramway system and sections of boulevards: Illustrated. Town Planning Review, 1(4), 294.

Anas, A., \& Arnott, R. (1994). The Chicago prototype housing market model with tenure choice and its policy applications. Journal of Housing Research, 5(1), 23.

Anderson, P., Owen, A., \& Levinson, D. (2012). The time between: Continuously-defined accessibility functions for schedule-based transportation systems. 92nd Annual Meeting of the Transportation Research Board.

Armstrong, R., \& Rodriguez, D. (2006). An evaluation of the accessibility benefits of commuter rail in eastern Massachusetts using spatial hedonic price functions. Transportation, 33(1), 21-43.

Ball, M., \& Kirwan, R. (1977). Accessibility and supply constraints in the urban housing market. Urban Studies, 14(1), 11-32.

Banister, D. (1978). The influence of habit formation on modal choice- A heuristic model. Transportation, 7(1), 5-33.

Banister, D. (2008). The sustainable mobility paradigm. Transport Policy, 15(2), 73-80.

Banister, D., \& Bowling, A. (2004). Quality of life for the elderly: The transport dimension. Transport policy, 11(2), 105-115.

Barrett, P. (1983). The automobile and urban transit: The formation of public policy in Chicago, 1900-1930: Temple University Press.

Batty, M. (2008). Fifty years of urban modeling: Macro-statics to micro-dynamics The dynamics of complex urban systems (pp. 1-20): Springer.

Belzer, D., \& Autler, G. (2002). Transit-oriented development: Moving from rhetoric to reality Paper presented at the The Brookings Institution Center on Urban and Metropolitan Policy Washington, D.C. .

Ben-Akiva, M., \& Lerman, S. (1974). Some estimation results of a simultaneous model of auto ownership and mode choice to work. Transportation, 3(4), 357-376.

Ben-Akiva, M., \& Lerman, S. (1979). Disaggregate travel and mobility choice models and measures of accessibility. Behavioural travel modelling, 654-679.

Black, A. (1990). The Chicago area transportation study: A case study of rational planning. Journal of Planning Education and Research, 10(1), 27-37.

Blumenberg, E., \& Ong, P. (2001). Cars, buses, and jobs-welfare participants and employment access in Los Angeles Sustainability and environmental concerns in transportation 2001: Planning and administration; energy and environment (pp. 22-31).

Boarnet, M., \& Sarmiento, S. (1998). Can land-use policy really affect travel behaviour? A study of the link between non-work travel and land-use characteristics. Urban Studies, 35(7), 1155-1169.

Boisjoly, G., \& El-Geneidy, A. (2016). Daily fluctuations in transit and job availability: A comparative assessment of time-sensitive accessibility measures. Journal of Transport Geography, 52, 73-81.

Brail, R., \& Klosterman, R. (2001). Planning support systems: integrating geographic information systems, models, and visualization tools. Redlands, CA: ESRI, Inc. 
Burchell, R., Listokin, D., \& Galley, C. (2000). Smart Growth: More than a ghost of urban policy past, less than a bold new horizon Housing Policy Debate, 11(4), 821-879.

Button, K. (2010). Transport economics: Edward Elgar Publishing.

Button, K., Doh, S., Hardy, M., Yuan, J., \& Zhou, X. (2010). The accuracy of transit system ridership forecasts and capital cost estimates. International Journal of Transport Economics, 155-168.

Button, K., Pearman, A., \& Fowkes, A. (1982). Car ownership modelling and forecasting.

Cervero, R. (2004). The built environment and travel: Evidence from the United States European Journal of Transport and Infrastructure Research, 2(3), 119-137.

Cervero, R., Ferrell, C., \& Murphy, S. (2002). Transit-oriented development and joint development in the United States: A literature review. Transit Cooperative Research Program (TCRP) research results digest(52).

Cervero, R., \& Kockelman, K. (1997). Travel demand and the 3Ds: Density, diversity, and design. Transportation Research Part D: Transport and Environment, 2(3), 199-219.

Chatman, D. (2006). Transit-oriented development and household travel: A study of California cities: Institute of Transportation Studies, School of Public Affairs, University of California, Los Angeles.

Chatman, D. (2009). Residential choice, the built environment, and nonwork travel: Evidence using new data and methods. Environment and planning. A, 41(5), 1072.

Chatman, D. (2013). Does TOD need the T? On the importance of factors other than rail access. Journal of the American Planning Association, 79(1), 17-31.

Congress for the New Urbanism. (1999). Charter of The New Urbanism 1st Edition. USA: McGraw-Hill Professional.

Currie, G. (2010). Quantifying spatial gaps in public transport supply based on social needs. Journal of Transport Geography, 18(1), 31-41. doi:10.1016/j.jtrangeo.2008.12.002

Davis, K. (1955). The origin and growth of urbanization in the world. American Journal of Sociology, 429-437.

De la Barra, T. (1989). Integrated land use and transport modelling: Decision chains and hierarchies. Cambridge, UK: Cambridge University Press.

Delbosc, A., \& Currie, G. (2011). Using Lorenz curves to assess public transport equity. Journal of Transport Geography, 19(6), 1252-1259. doi:10.1016/j.jtrangeo.2011.02.008

Downs, A. (2004). Still stuck in traffic: Coping with peak-hour traffic congestion. Washington, DC.: The Brookings Institution.

Downs, A. (2005). Smart growth: Why we discuss it more than we do it. Journal of the American Planning Association, 71(4), 367-378.

Du, H., \& Mulley, C. (2006). Relationship between transport accessibility and land value: Local model approach with geographically weighted regression. Transportation Research Record(1977), 197-205.

Duany, A. (2013). 20 years of New Urbanism. In E. Talen (Ed.), Charter of New Urbansim, Second Edition (pp. 9-13). United States of America: McGraw-Hill Education.

Duany, A., Speck, J., \& Lydon, M. (2010). The smart growth manual: McGraw-Hill.

Dunphy, R., Cervero, R., Dock, F., McAvery, M., Porter, D., \& Swenson, C. (2004). Developing around transit: Strategies and solutions that work. Washington, D.C.: Urban Land Institute.

El-Geneidy, A., Cerdá, A., Fischler, R., \& Luka, N. (2011). Evaluating the impacts of transportation plans using accessibility measures. Canadian journal of urban research, 20(1), 81. 
El-Geneidy, A., \& Levinson, D. (2006). Access to destinations: Development of accessibility measures. Retrieved from St-Paul, Minnesota, U.S.: http://nexus.umn.edu/projects/Access/Access-FinalReport.pdf

El-Geneidy, A., van Lierop, D., \& Wasfi, R. (In press). Do people value bicycle sharing? A multilevel longitudinal analysis capturing the impact of bicycle sharing on residential sales in Montreal, Canada. Transport policy.

Ettema, D., Gärling, T., Olsson, L., \& Friman, M. (2010). Out-of-home activities, daily travel, and subjective well-being. Transportation research part A: policy and practice, 44(9), 723732.

Ewing, R., \& Cervero, R. (2010). Travel and the built environment. Journal of the American Planning Association, 76(3), 1-30.

Flanagan, E., Lachapelle, U., \& El-Geneidy, A. (2016). Riding tandem: Does cycling infrastructure investment mirror gentrification and privilege in Portland, Oregon, and Chicago, Illinois? Transportation Research Record(16-1493).

Foster, M. (1981). From streetcar to superhighway (pp. 151-176): Temple University Press, Philadelphia.

Freeman, L. (2005). Displacement or succession? Residential mobility in gentrifying neighborhoods. Urban Affairs Review, 40(4), 463-491.

Garin, R. (1966). A matrix formulation of the lowry model for intrametropolitan activity allocation. Journal of the American Institute of Planners, 32(6), 361-364.

Garrison, W., \& Levinson, D. (2006). The transportation experience: Policy, planning, and deployment: Oxford University Press.

Gee, G., \& Takeuchi, D. (2004). Traffic stress, vehicular burden and well-being: A multilevel analysis. Social Science \& Medicine, 59(2), 405-414.

Geurs, K., \& van Wee, B. (2004). Accessibility evaluation of land-use and transport strategies: Review and research directions. Journal of Transport Geography, 12, 127-140.

Glass, R. (1964). London: Aspects of change (Vol. 3): MacGibbon \& Kee.

Golub, A., \& Martens, K. (2014). Using principles of justice to assess the modal equity of regional transportation plans. Journal of Transport Geography, 41, 10-20.

Grengs, J. (2010). Job accessibility and the modal mismatch in Detroit. Journal of Transport Geography, 18(1), 42-54.

Grube-Cavers, A., \& Patterson, Z. (2015). Urban rapid rail transit and gentrification in Canadian urban centres: A survival analysis approach. Urban Studies, 52(1), 178-194.

Guiliano, G. (2004). Land use impacts of transportation investments-Highway and transit. In S. Hanson \& G. Guiliano (Eds.), The Geography of Urban Transportation (Third ed.). New York: The Guilford Press.

Gutierrez, J. (2009). Transport and accessibility. In R. Kitchin \& N. Thrift (Eds.), International Encyclopedia of Human Geography (pp. 410-417). Oxford: Elsevier.

Halden, D. (2011). The use and abuse of accessibility measures in UK passenger transport planning. Research in Transportation Business \& Management, 2, 12-19.

Handy, S., Cao, X., \& Mokhtarian, P. (2006). Self-selection in the relationship between the built environment and walking: Empirical evidence from Northern California. Journal of the American Planning Association, 72(1), 55-74.

Handy, S., \& Niemeier, D. (1997). Measuring accessibility: An exploration of issues and alternatives. Environment and Planning A, 29, 1175-1194.

Hansen, W. (1959). How accessibility shapes land use. Journal of the American Institute of Planners, 25(2), 73-76. 
Hansson, E., Mattisson, K., Björk, J., Östergren, P., \& Jakobsson, K. (2011). Relationship between commuting and health outcomes in a cross-sectional population survey in southern Sweden. BMC Public Health, 11(1), 1.

Hatzopoulou, M. (2009). An integrated multi-model approach for predicting the impact of household travel on urban air quality and simulating population exposure.

Heath, G., Brownson, R., Kruger, J., Miles, R., Powell, K., Ramsey, L., \& Services, T. F. o. C. P. (2006). The effectiveness of urban design and land use and transport policies and practices to increase physical activity: A systematic review. Journal of Physical Activity \& Health, 3, S55.

Hensher, D. (1975). Perception and commuter modal choice-An hypothesis. Urban Studies, 12(1), 101-104.

Hofstad, H. (2012). Compact city development: High ideals and emerging practices European Journal of Spatial Development.

Hurst, M. E. (1969). The structure of movement and household travel behaviour. Urban Studies, 6(1), 70-82.

lacono, M., Levinson, D., \& El-Geneidy, A. (2008). Models of transportation and land use change: A guide to the territory. Journal of Planning Literature, 22(4), 323-340.

Jones, P., \& Lucas, K. (2012). The social consequences of transport decision-making: clarifying concepts, synthesising knowledge and assessing implications. Journal of Transport Geography, 21, 4-16.

Kain, J., \& Beesley, M. (1965). Forecasting car ownership and use. Urban Studies, 2(2), 163-185.

Kain, J., \& Fauth, G. (1978). The impact of urban development on auto ownership and transit use. Real Estate Economics, 6(3), 305-326.

Katoshevski, R., Glickman, I., Ishaq, R., \& Shiftan, Y. (2015). Integrating activity-based traveldemand models with land-use and other long-term lifestyle decisions. Journal of Transport and Land Use, 8(3).

Koenig, J. (1980). Indicators of urban accessibility: Theory and application. Transportation, 9(2), 145-172.

Langlois, M., van Lierop, D., Wasfi, R., \& El-Geneidy, A. (2015). Chasing sustainability: Do new Transit-Oriented Development residents adopt more sustainable modes of transportation? Transportation Research Record: Journal of the Transportation Research Board(2531), 83-92.

Leccese, M., \& McCormick, K. (2000). Charter of the new urbanism: McGraw-Hill Professional.

Legrain, A., Buliung, R., \& El-Geneidy, A. (2015). Who, what, when and where: Revisiting the influences of transit mode share. Transportation Research Record.

Legrain, A., Eluru, N., \& El-Geneidy, A. (2015). Am stressed, must travel: The relationship between mode choice and commuting stress. Transportation Research Part F: Traffic Psychology and Behaviour, 34, 141-151.

Levine, J., Grengs, J., Shen, Q., \& Shen, Q. (2012). Does accessibility require density or speed? A comparison of fast versus close in getting where you want to go in US metropolitan regions. Journal of the American Planning Association, 78(2), 157-172.

Levinson, D. (1998). Accessibility and the journey to work. Journal of Transport Geography, 6(1), 11-21.

Levinson, D. (2007). Density and dispersion: The co-development of land use and rail in London. Journal of Economic Geography, 1-23.

Levinson, D., \& Krizek, K. (2008). Planning for place and plexus: Metropolitan land use and transport. New York: Routledge. 
Leyden, K. (2003). Social capital and the built environment: The importance of walkable neighborhoods. American Journal of Public Health, 93(9), 1546-1551.

Lowry, I. (1964). A model of metropolis. The RAND Corporation, California: Santa monica.

Lubitow, A., \& Miller, T. (2013). Contesting sustainability: Bikes, race, and politics in Portlandia. Environmental Justice, 6(4), 121-126.

Mackett, R. (1983). Leeds Integrated Land-Use Transport Model (LILT) (0305-1315). Retrieved from Crowthorne, UK:

Manaugh, K., \& El-Geneidy, A. (2011). Who benefits from new transportation infrastructure? Using accessibility measures to evaluate social equity in transit provision. In K. Geurs, K. Krizek, \& A. Reggiani (Eds.), Accessibility and Planning: Challenges for Europe and North America. London, UK Edward Elgar.

Manaugh, K., \& El-Geneidy, A. (2014). Disentangling self-selection and transit availability influences in mode choice decision making. Paper presented at the World Symposium on Land use and Transport (WSTLUR), Delf in the Netherlands. http://tram.mcgill.ca/Research/Publications/Self\%20selection.pdf

Martens, K., Golub, A., \& Robinson, G. (2012). A justice-theoretic approach to the distribution of transportation benefits: Implications for transportation planning practice in the United States. Transportation research part A: policy and practice, 46(4), 684-695.

Martinez, F. (1996). MUSSA: land use model for Santiago city. Transportation Research Record: Journal of the Transportation Research Board(1552), 126-134.

McClintock, M. (1926). Report and Recommendations of the Metropolitan Street Traffic Survey. Chicago: Chicago Association of Commerce.

McFadden, D. (2001). Economic choices. The American Economic Review, 91(3), 351-378.

McFadden, D., Johnson, M. I., \& Reid, F. (1973). Travel demand forecasting study Bart Impact Studies Final Report Series Part III.

McNally, M. (2007). The four step model. Handbook of transport modelling, 1, 35-41.

Miller, E., \& Roorda, M. (2003). Prototype model of household activity-travel scheduling. Transportation Research Record: Journal of the Transportation Research Board(1831), 114-121.

Neff, J., \& Dickens, M. (2013). 2013 Public Transportation Fact Book. Washington, D.C.: American Public Transportation Association.

Nelson, R. (1973). Accessibility and rent: Applying Beckers 'time price' concept to the theory of residential location. Urban Studies, 10(1).

Newbold, K., Scott, D., Spinney, J., Kanaroglou, P., \& Páez, A. (2005). Travel behavior within Canada's older population: A cohort analysis. Journal of Transport Geography, 13(4), 340-351.

Newman, P., \& Kenworthy, J. (1996). The land use - transport connection: An overview Land Use Policy, 13(1), 1-22.

Ory, D., \& Mokhtarian, P. (2005). When is getting there half the fun? Modeling the liking for travel. Transportation research part A: policy and practice, 39(2), 97-123.

Owen, A., \& Levinson, D. M. (2015). Modeling the commute mode share of transit using continuous accessibility to jobs. Transportation research part A: policy and practice, 74, 110-122. doi:10.1016/j.tra.2015.02.002

Paez, A., Scott, D., \& Morency, C. (2012). Measuring accessibility: Positive and normative implementations of various accessibility indicators. Journal of Transport Geography, 25, 141-153.

Pereira, R., Schwanen, T., \& Banister, D. (2016). Distributive justice and equity in transportation. Transport Reviews. 
Pfaffenbichler, P. (2003). The strategic, dynamic and integrated urban land use and transport model MARS (Metropolitan Activity Relocation Simulator). Unpublished PhD Thesis, Technische Universitaet Wien http://www.ivv.tuwien.ac.at/publications/online/MARSsmallestsize.pdf.

Pfaffenbichler, P. (2011). Modelling with systems dynamics as a method to bridge the gap between politics, planning and science? Lessons learnt from the development of the land use and transport model MARS. Transport Reviews, 31(2), 267-289.

Phillipson, C. (2011). Developing age-friendly communities: New approaches to growing old in urban environments Handbook of Sociology of Aging (pp. 279-293): Springer.

Pivo, G., \& Fisher, J. (2011). The walkability premium in commercial real estate investments. Real Estate Economics, 39(2), 185-219.

Podobnik, B. (2002). Assessing the social and environmental achievements of new urbanism: evidence from Orenco Station Paper presented at the Annual Meeting of the American Sociological Association San Francisco, California

Preston, J., \& Rajé, F. (2007). Accessibility, mobility and transport-related social exclusion. Journal of Transport Geography, 15, 151-160.

Proffitt, D., Bartholomew, K., Ewing, R., \& Miller, H. (2015). Accessibility planning in american metropolitan areas: Are we there yet? Paper presented at the Transportation Research Board 94th Annual meeting, Washington, D.C.

Putman, S. (2013). Integrated Urban Models Volume 1: Policy Analysis of Transportation and Land Use (RLE: The City) (Vol. 1): Routledge.

Raff, D. (1991). Making cars and making money in the interwar automobile industry: Economies of scale and scope and the manufacturing behind the marketing. Business History Review, 65(04), 721-753.

Renne, J., \& Wells, J. (2004). Emerging European-style planning in the USA: transit-oriented development. World Transport Policy \& Practice, 10, 12-24.

Rosenbloom, S. (2001). Sustainability and automobility among the elderly: An international assessment. Transportation, 28(4), 375-408.

Salvini, P., \& Miller, E. (2005). ILUTE: An operational prototype of a comprehensive microsimulation model of urban systems. Networks and Spatial Economics, 5(2), 217234.

Samuelson, M. (2009). Reducing cars and increasing development: How the creation of a viable transit oriented development corridor in Aarlington, Virginia has sparker growth Cities of the 21st Century, 1(1).

Sanchez, T., Shen, Q., \& Peng, Z. (2004). Transit mobility, jobs access and low-income labour participation in US metropolitan areas. Urban Studies, 41(7), 1313-1331.

Shahrooz, B. (2011). Design of concrete structures using high-strength steel reinforcement (Vol. 679): Transportation Research Board.

Shephard, R. (2008). Is active commuting the answer to population health? Sports Medicine, 38(9), 751-758.

Smith, N. (1982). Gentrification and uneven development. Economic Geography, 58(2), 139-155.

Special Roads Act 1949, (1949).

Talen, E. (2013). Charter of the new urbanism: McGraw-Hill Prof Med/Tech.

Train, K. (1980). A structured logit model of auto ownership and mode choice. The Review of Economic Studies, 47(2), 357-370.

Translink. (2010). Transit-oriented communities: A literature review on the relationship between the built environment and transit ridership Retrieved from Vancouver, B.C. :

United Nations. (2013). World Population Ageing 2013. Retrieved from New York: 
United States Department of Health, \& Human Services. (1996). Physical activity and health: A report of the Surgeon General. Atlanta, Ga: Centres for Disease Control and Prevention.

United States Surgeon General. (2015). Step it up! The Surgeon General's call to action to promote walking and walkable communities. Retrieved from http://www.surgeongeneral.gov/library/calls/walking-and-walkable-communities/

Van Acker, V., Van Wee, B., \& Witlox, F. (2010). When transport geography meets social psychology: Toward a conceptual model of travel behaviour. Transport Reviews, 30(2), 219-240.

van Lierop, D., Maat, K., \& El-Geneidy, A. (2016). Talking TOD: learning about transit-oriented development in the United States, Canada, and the Netherlands. Journal of Urbanism: International Research on Placemaking and Urban Sustainability, 1-14.

van Wee, B. (2015). Viewpoint: Toward a new generation of land use transport interaction models. Journal of Transport and Land Use, 8(3).

Vuchic, V. (2007). Urban Transit - Systems and Technology. Hoboken, New Jersey: John Wiley and Sons, Inc.

Wachs, M. (1993). Learning from Los Angeles: Transport, urban form, and air quality. Transportation, 20, 329-354.

Wachs, M., \& Kumagai, T. (1973). Physical accessibility as a social indicator. Socio-Economic Planning Sciences, 7(5), 437-456.

Waddell, P. (2000). A behavioral simulation model for metropolitan policy analysis and planning: Residential location and housing market components of UrbanSim. Environment and planning B: Planning and Design, 27(2), 247-263.

Waddell, P., \& Borning, A. (2004). A case study in digital government developing and applying urbansim, a system for simulating urban land use, transportation, and environmental impacts. Social Science Computer Review, 22(1), 37-51.

Waddell, P., Outwater, M., Bhat, C., \& Blain, L. (2002). Design of an integrated land use and activity-based travel model system for the Puget Sound region. Transportation Research Record: Journal of the Transportation Research Board(1805), 108-118.

Waddell, P., Wang, L., Charlton, B., \& Olsen, A. (2010). Microsimulating parcel-level land use and activity-based travel: Development of a prototype application in San Francisco. Journal of Transport and Land Use, 3(2).

Walks, A., \& Maaranen, R. (2008). Gentrification, social mix, and social polarization: Testing the linkages in large Canadian cities. Urban Geography, 29(4), 293-326.

Weber, A., \& Pick, G. (1909). Über den Standort der Industrien: Reine Theorie des Standorts: JCB Mohr.

Wegener, M. (2004). Overview of land-use transport models. In D. Hensher, K. Button, K. Haynes, \& P. Stopher (Eds.), Handbook of Transport Geography and Spatial Systems (Handbooks in Transport, Volume 5) (pp. 127-146).

Wegener, M. (2011). From macro to micro-how much micro is too much? Transport Reviews, 31(2), 161-177.

Weiner, E. (1999a). Urban transportation planning in the United States: An historical overview. Westport, CT, USA: Greenwood Publishing Group.

Weiner, E. (1999b). Urban transportation planning in the United States: History, Policy, and Practice. New York, USA: Springer. 